infant." According to one source cited by Williams, Malevich declared himself (at a public lecture connected with the " 0.10 " exhibition) to be the embodiment of a messianic vision: "I am the royal infant . . . tens of thousands of years have prepared my birth" (p. 123).

In any book of this scope, disagreements about specific areas are bound to occur. Williams's constant stress on the artists' need for success and public recognition as a motive for artistic innovation will jar the sensibilities of readers trained in art history. Also, for historians of Russian art, the degree of emphasis to be placed on "Western influences" is always a delicate question. Williams stands firmly on the side of those who regard a constant fertilization of the Russian art world by Western ideas as the key to progress and innovation. At times Artists in Revolution seems to exaggerate the backwardness of Russian art at the turn of the century or to overdramatize the conflict of existing trends with Western innovation. For example, the so-called left wing of the Mir iskusstva group is described as "more Europeanized" than the older generation of Alexandre Benois and Sergei Diaghilev (p. 60). On the whole, it is extremely difficult to see Dobuzhinskii as more Western or, indeed, more "innovative" in style than the original members of the Mir iskusstva group, although his work for satirical journals after the 1905 Revolution does place him in a left-wing camp politically.

Artists in Revolution presents a rich collection of information, including material on once popular but now little known intellectual sources, such as Claude Bragdon's Primer of Higher Space and its impact-albeit indirect-on Malevich. What emerges most strongly from Williams's arguments it the degree to which revolution fulfilled a personal need for various artists-most notably for Mayakovsky, who is certainly the central figure of this book and the best illustration of the author's thesis. Williams's book poses the question of artists in revolution with a strongly personal emphasis which is bound to inspire debate among specialists in the various fields it touches.

JANET KENNEDY Indiana University

\title{
RUSSIAN FUTURISM, URBANISM, AND ELENA GURO. By Kjeld Bjørnager Jensen. Årkus, Denmark: Arkona, 1977. iv, 204 pp. Paper.
}

The very title of this book indicates a peculiar historical perspective: apart from the works of Mayakovsky, Russian Futurism is not noteworthy for its urbanism, and Elena Guro is known as an author who was dedicated to nature. If Russian urbanism were Jensen's main concern, as it appears to be, then his centerpiece should have been Mayakovsky, not Guro. By his own count, only four pieces by Guro exploit the city theme, and three of those were relatively early works. In any case, he offers a survey history of Russian urbanism in which Guro is presented as a transitional figure between the Symbolists-Briusov, Belyi, and Blok-and her fellow Futurists. Jensen distinguishes Guro, whom he calls an impressionist, from the other Futurists, whom he considers expressionistic. His extensive analysis of her three urbanistic prose pieces (in Sharmanka) suggests a sadomasochistic motivation for her increasing hostility to the city. Yet he draws convincing parallels between Guro's "tragic" view of the city and the early Mayakovsky, while also showing what might be owed to Briusov or Marinetti. Furthermore, he expounds the notion that the minor poets of "The Mezzanine of Poetry" (headed by Vadim Shershenevich) were the chief exponents of urbanism among the Futurists. No mention is made of the appearance of the city in the works of the Acmeists or, subsequently, in the tavern poetry of Esenin. The book includes a useful bibliography. 